\title{
Essential oils: in vitro activity against Leishmania amazonensis, cytotoxicity and chemical composition
}

\author{
Milene Aparecida Andrade ${ }^{1,2}$, Clênia dos Santos Azevedo ${ }^{1}$, Flávia Nader Motta ${ }^{1,2}$, Maria Lucília dos Santos ${ }^{3}$, \\ Camila Lasse Silva ${ }^{1}$, Jaime Martins de Santana ${ }^{1}$ and Izabela M. D. Bastos ${ }^{1 *}$
}

\begin{abstract}
Background: The current chemotherapy for cutaneous leishmaniosis (CL) has a series of drug limitations such as toxic side effects, long duration, high costs and drug resistance, which requires the development of new drugs or effective alternatives to the $\mathrm{CL}$ treatment. Essential oils (EOS) are complex mixtures of secondary metabolites from various plants. It has been shown that several EOs, or their constituents, have inhibitory activity against protozoa. Thus, this study aims to evaluate the biological activity of different essential oils (EOs) on Leishmania (L.) amazonensis promastigotes forms, as well as their cytotoxicity on mammalian cells and chemical composition.
\end{abstract}

Methods: Sixteen EOs were evaluated by mean of $\mathrm{IC}_{50} / 24 \mathrm{~h}$ and cytotoxicity against $\mathrm{L}_{6}$ cells $\left(\mathrm{CC}_{50} / 24 \mathrm{~h}\right)$ using Resazurin assay. Only those EOs that presented better results for $\mathrm{IC}_{50} / 24 \mathrm{~h}$ were submitted to $\mathrm{GC}-\mathrm{MS}$ analysis to determine their chemical constitution.

Results: The EO from Cinnamodendron dinisii, Matricaria chamomilla, Myroxylon peruiferum, Salvia sclarea, Bulnesia sarmientoi, Ferula galbaniflua, Siparuna guianensis and Melissa officinalis were the most active against L. amazonensis with IC50/24 h ranging from 54.05 to $162.25 \mu \mathrm{g} / \mathrm{mL}$. Analysis of EOs by GC-MS showed mainly the presence of $\beta$-farnesene (52.73\%) and bisabolol oxide (12.09\%) for M. chamomilla; a-copaene (13.41\%), safrole (8.35\%) and $\delta$-cadinene (7.08 \%) for M. peruiferum; linalool (28.80\%) and linalyl acetate $(60.08 \%)$ for S. sclarea; guaiol (48.29\%) and 2-undecanone (19.49\%) for B. sarmiento; ethyl phthalate (13.09\%) and methyl-8-pimaren-18-oate (41.82 \%) for F. galbaniflua; and neral (37.18\%) and citral (5.02\%) for M. officinalis.

Conclusion: The EO from F. galbaniflua showed to be effective against $L$. amazonensis promastigotes forms and presented low cytotoxic activity against $L 6$ cells. Thus, it represents a strong candidate for future studies aiming its molecular activity on these pathogenic parasites.

Keywords: Secondary metabolites, Anti-Leishmania, Natural products, Ferula galbaniflua

\section{Background}

Leishmaniasis, the third most important vector-borne diseases, is caused by a protozoan parasite of the genus Leishmania, which is transmitted to human by the bite of sand flies. Leishmaniasis represents a complex disease with diverse clinical manifestations and poses a public health problem since it is a neglected tropical disease

\footnotetext{
* Correspondence: dourado@unb.br

'Pathogen-Host Interface Laboratory, Department of Cell Biology, The University of Brasília, Campus Darcy Ribeiro, Bloco I, Brasília, DF CEP 70910-900, Brazil

Full list of author information is available at the end of the article
}

with current high worldwide incidence [1, 2]. Globally, more than 12 million individuals are infected, with another 350 million at risk of infection, and nearly 2 million new cases are reported annually worldwide [3]. The disease is prevalent in 16 developed and 72 developing countries; nevertheless $90 \%$ of cases are reported in three regions: Sudan/Ethiopia/Kenya, India/Bangladesh/ Nepal and Brazil with as many as 0.02 to 0.04 million deaths every year $[3,4]$.

Leishmaniasis can be divided into three forms, varying in severity from self-healing cutaneous lesions, dermatological ulcers in cutaneous leishmaniasis (CL), destructive 
form of mucocutaneous leishmaniasis, to deadly form of visceral leishmaniasis (VL) [5]. CL is characterized by ulcers on the skin that are often formed at the site of the insect vector bite. Those ulcers can undergo metastasis of the nasopharyngeal mucosa developing to tissue destruction, depending on the species of Leishmania involved [6]. Leishmania (Viannia) braziliensis and Leishmania (V.) panamensis are responsible for cases of mucocutaneous leishmaniasis in the Americas, although $L$. (V.) guyanensis and L. (L.) amazonensis have been identified, especially, in immuno-compromised hosts [6].

The first-line drugs for systemic treatment of leishmaniasis are parenterally administered antimonials such as the sodium stibogluconate (Pentostam ${ }^{\oplus}$ ) and the $\mathrm{N}$ methyl glucamine antimoniate (Glucantime ${ }^{\oplus}$ ) [7, 8] generally required for the treatment of $\mathrm{CL}$ in the New World due to the risk of mucosal involvement [9]. This current chemotherapy presents several issues such as high cost, difficult administration and elevated toxicity, associated with serious side effects [10], for instance musculoskeletal pain, gastrointestinal disturbances, mild to moderate headache, electrocardiographic QTs interval prolongation and mild to moderate increase of liver and pancreatic enzymes [11]. Second-line drug Pentamidine and amphotericin B are not widely used due to their high toxicity and cost. Miltefosine, the first oral antileishmanial drug, is the treatment of choice for diffuse cutaneous leishmaniasis and New World cutaneous leishmaniasis caused by Leishmania braziliensis but increasing resistance to this drug has been notified [12].

All antileishmanial drugs except miltefosine have to be administrated parenterally. Most of these drugs are toxic, requires prolonged hospitalization and close monitoring, which makes the treatment costly and beyond the reach of most patients. Consequently, the development of alternative therapies is a priority for the treatment of leishmaniasis. As a strategy, the investigation of extracts and compounds, with biological activity, isolated from plants and used in traditional medicine is a promising in the research field for compounds with potential action for the prophylaxis and chemotherapy of CL [13].

Essential oils (EOs) are complex mixtures of secondary metabolites isolated from plants. In these mixtures, there are 10-60 constituents at different concentrations, but usually only 2-3 major constituents determine the biological properties of the EO [14]. Those compounds and their constituents present a broad pharmacological spectrum, and they are used as analgesics, sedatives, antiinflammatory, and anti-spasmodic drugs, as well as antimicrobials, antiprotozoals and antihelmintics $[13,15,16]$. It has been shown that several EOs or their constituents have inhibitory activity on protozoa, especially Leishmania [17-19]. For instance, Santos and colleagues demonstrated that copaiba oil from Copaifera martii is a safer, shorter, less-expansive, and more easily administered antileishmanial drug [18]. Therefore, the purpose of this present work was to analyze the effect of sixteen EOs biological potential on L. amazonensis promastigotes forms and L6 cells and chemical constitution, by GC-MS, of those EOs that showed better leishmanicidal results.

\section{Methods}

\section{Essential oils}

EOs of Litsea cubeba fruits; Lavandula officinalis, Matricaria chamomilla and Cananga odorata flowers; Elettaria cardamomum seeds; Cinnamomum camphora, Myroxylon peruiferum and Bulnesia sarmientoi barks; Ferula galbaniflua resin; Salvia sclarea, Foeniculum officinalis, Cordia verbenaceae, and Melissa officinalis leaves; Pelargonium graveolens leaves and stems were purchased from QUINARI Cosmetic and Fragrances Inc. (Maringá-PR, Brazil) with lot number 0717/05209/F. EOs of Cinnamodendron dinisii and Siparuna guianensis leaves were obtained as described by Andrade et al. [20].

Firstly, EOs and Amphotericin B $250 \mu \mathrm{g} / \mathrm{mL}$ (SigmaAldrich, St. Louis, USA) were diluted in dimethylsulfoxide (DMSO) at $100 \mathrm{mg} / \mathrm{mL}$ and $50 \mu \mathrm{g} / \mathrm{mL}$, respectively. For use, the stock was diluted 5:100 in either Schneider (Sigma-Aldrich) or RPMI-1640 (Sigma-Aldrich) media (sub stock). DMSO final concentration in the experiments never exceeded $0.5 \%$, a concentration that is not harmful to parasites and L6 cells [13]. Stocks were stored at $4{ }^{\circ} \mathrm{C}$ in the dark, to avoid degradation [21]. The sub stock was freshly prepared before use.

\section{Chemical composition of EOs}

Gas chromatography-mass spectrometry (GC-MS) analysis was performed using a Shimadzu GC-2010 gas chromatograph coupled with GCMS-QP2010 Plus equipped with auto sampler (model AOC-20i, Shimadzu, Columbia, $\mathrm{MD}, \mathrm{USA}$ ) and GC-MS Solution software. Investigation was performed with a Rtx-5MS capillary column (30 $\mathrm{mm} \times$ $0.25 \mathrm{~mm} \times 0.25 \mu \mathrm{m})$ at programmed temperature ranging from 60 to $250{ }^{\circ} \mathrm{C}$ at $3{ }^{\circ} \mathrm{C} / \mathrm{min}$. Analysis conditions were: injector temperature $250{ }^{\circ} \mathrm{C}$, ion source interface temperature $300{ }^{\circ} \mathrm{C}$, analysis of masses between $40-$ $350 \mathrm{~m} / \mathrm{z}$, electron impact at $70 \mathrm{eV}$, column head pressure at constant pressure of $59 \mathrm{kPa}$, column flow $1.02 \mathrm{~mL} / \mathrm{min}$, gas linear velocity: $36.8 \mathrm{~cm} / \mathrm{s}$, carrier gas: helium, injected volume $1 \mu \mathrm{L}(1: 1000$ in hexane) in splitless. Constituents of EOs were identified by comparing their mass spectral pattern and retention indexes (RI) relative to a standard n-alkane series $\left(\mathrm{C}_{9}-\mathrm{C}_{24}\right)$ with those known in the literature and the Wiley W9N08 database $[13,22]$. 


\section{Parasites and culture conditions}

The promastigotes forms of $L$. amazonensis (strain $\mathrm{MHOM} / \mathrm{BR} / 77 / \mathrm{LTB} 0016)$ were maintained at $28{ }^{\circ} \mathrm{C}$ in Schneider medium supplemented with $10 \%$ fetal bovine serum (FBS) and $100 \mu \mathrm{g} / \mathrm{mL}$ gentamicin, with weekly passages. For the screening of EOs biological potential, promastigotes were collected from cultures at the midlog phase of growth (3-day-old culture). The parasite strain was obtained from Fiocruz-COLPROT (Coleção de Protozoários da Fiocruz).

\section{Antileishmanial activity of essential oils in vitro}

EOs serial dilutions, from 500 to $31.25 \mu \mathrm{g} / \mathrm{mL}$, were prepared on a 96-well cell culture plate. Afterwards, $1.35 \times$ $10^{6}$ parasite $/ \mathrm{mL}$ culture resuspended in $150 \mu \mathrm{L}$ were added to the plates and incubated for $24 \mathrm{~h}$ at $28{ }^{\circ} \mathrm{C}$. After this period, $20 \mu \mathrm{L}$ of Resazurin solution were added to a $2 \mathrm{mM}$ final concentration in all wells [23, 24]. The plates were incubated for further $4 \mathrm{~h}$ at $37^{\circ} \mathrm{C}$ followed by the fluorescence measurement under $570 \mathrm{~nm}_{\mathrm{ex}} / 595 \mathrm{~nm}_{\mathrm{em}}$ in the microplate reader SpectraMax M5 (Molecular Devices, Sunnyvale, CA, USA).

In vitro experiment was performed in triplicate and repeated twice independently. DMSO was used as control in the same final concentration found in each dilution. Amphotericin B was used as positive control at final concentration ranging from 312.5 to $19.56 \mathrm{ng} / \mathrm{mL}$.

The percentage of viable promastigotes cells was determined by the equation [25]:

$$
\% \mathrm{P}=(100 \times \mathrm{Fa}) / \mathrm{Fc}
$$

Where \%P: percentage of viable promastigotes cells; Fc: control fluorescence units; Fa: fluorescence units emitted by the analyzed samples (with inhibitor).

\section{Cytotoxic activity of essential oils in vitro}

Uninfected L6 cell monolayers were washed with Phosphate Buffered Saline (PBS) for $5 \mathrm{~min}$ at $37{ }^{\circ} \mathrm{C}$, washed with RPMI medium pH 7.4+2.5\% FBS, centrifuged at $200 \mathrm{~g}$ for $10 \mathrm{~min}$ at $4{ }^{\circ} \mathrm{C}$, resuspended in the same medium and, finally, seeded into 96 -well plates $\left(5 \times 10^{4}\right.$ cells/well). Plates were incubated at $37{ }^{\circ} \mathrm{C}$ for $24 \mathrm{~h}$, then the medium was removed and cells were washed with PBS. Diluted EOs were added to overnight-adhered L6 cells and incubated for more $24 \mathrm{~h}$ at $37^{\circ} \mathrm{C}$. Cell viability was assessed by $2 \mathrm{mM}$ Resazurin as described above.

The percentage of viable cells was determined by the equation [25]:

$$
\% \mathrm{~V}=(100 \times \mathrm{Fa}) / \mathrm{Fc}
$$

Where $\% \mathrm{~V}$ is the percentage of viable cells, Fc: control fluorescence units; Fa: fluorescence units emitted by the analyzed samples (with inhibitor). The selectivity index (SI) was calculated by dividing $\mathrm{CC}_{50}$ for the $\mathrm{IC}_{50}$.

\section{Statistical analysis}

For both in vitro EOs biological potential, a randomized complete block design (RBD) test was used, with 5 concentrations, 3 repetitions and 2 experiments (blocks) for each sample. The statistical program used was SISVAR [26]. Data were submitted to analysis of variance and the averages compared by Scott-Knott test and regression, both $5 \%$ probability. The adjusted equations were used to calculate the concentration needed to cripple $50 \%$ of L6 cells $\left(\mathrm{CC}_{50}\right)$ or $50 \%$ of the parasites $\left(\mathrm{IC}_{50}\right)$.

\section{Results}

\section{Antileishmanial and cytotoxic activity of essential oils in} vitro

Growth inhibitory activity by the selected EOs was performed on $L$. amazonensis promastigotes forms at concentrations ranging from 30 to $500 \mu \mathrm{g} / \mathrm{mL}$. In the test, the EOs of L. cubeba, E. cardamomum, L. officinalis, C. camphora and C. odorata did not show activity at $500 \mu \mathrm{g} / \mathrm{mL}$ (Table 1). Lower concentrations of the remaining EOs were then evaluated to estimate the $\mathrm{IC}_{50} / 24 \mathrm{~h}$ (Table 1 ). The most effective EO was of the one from $S$. guianensis $(48.55 \pm 3.64 \mu \mathrm{g} / \mathrm{mL})$, followed by C. dinisii $(54.05 \pm 4.88 \mu \mathrm{g} / \mathrm{mL})$, M. chamomilla $(60.16 \pm$ $4.24 \mu \mathrm{g} / \mathrm{mL}), C$. verbenaceae $(64.75 \pm 2.04 \mu \mathrm{g} / \mathrm{mL}), B$. sarmientoi $(85.56 \pm 3.38 \mu \mathrm{g} / \mathrm{mL})$, F. galbaniflua $(95.70 \pm$ $1.82 \mu \mathrm{g} / \mathrm{mL})$, M. officinalis $(132.02 \pm 3.14 \mu \mathrm{g} / \mathrm{mL}), M$. peruiferum $(162.25 \pm 1.57 \mu \mathrm{g} / \mathrm{mL})$, S. sclarea (325.92 \pm $8.58 \mu \mathrm{g} / \mathrm{mL})$, F. officinalis $(328,28 \pm 6,80 \mu \mathrm{g} / \mathrm{mL})$ and $P$. graveolens $(363.71 \pm 6.77 \mu \mathrm{g} / \mathrm{mL})$. The $\mathrm{IC}_{50} / 24 \mathrm{~h}$ of Amphotericin B was $0.83 \pm 0.03 \mu \mathrm{g} / \mathrm{mL}$ (Table 1).

The cytotoxicity against L6 cells and L. amazonensis were compared using the selectivity index (SI) (Table 1). Higher values of SI means more promising compounds for developing antileishmanial drugs. The SI measures the compound's level of selectivity towards L. amazonensis. Evaluation of cytotoxicity showed that the least cytotoxic EO was that of $C$. camphora $\left(\mathrm{CC}_{50} / 24 \mathrm{~h}=>500.00 \mu \mathrm{g} /\right.$ $\mathrm{mL})$, followed by $E$. cardamomum $(439.57 \pm 2.27 \mu \mathrm{g} / \mathrm{mL}), L$. officinalis $(377.56 \pm 8.91 \mu \mathrm{g} / \mathrm{mL})$, F. galbaniflua $(377.26 \pm$ $2.71 \mu \mathrm{g} / \mathrm{mL})$, S. sclarea $(375.37 \pm 3.62 \mu \mathrm{g} / \mathrm{mL})$, P. graveolens $(368.39 \pm 3.90 \mu \mathrm{g} / \mathrm{mL})$, F. officinalis $(368.27 \pm 3.81 \mu \mathrm{g} / \mathrm{mL})$, M. officinalis $(297.45 \pm 1.32 \mu \mathrm{g} / \mathrm{mL})$, L. cubeba $(180.72 \pm$ $1.37 \mu \mathrm{g} / \mathrm{mL}), M$. chamomilla $(173.04 \pm 1.24 \mu \mathrm{g} / \mathrm{mL}), B$. sarmientoi $(163.46 \pm 1.77 \mu \mathrm{g} / \mathrm{mL})$, M. peruiferum $(160.80 \pm$ $1.62 \mu \mathrm{g} / \mathrm{mL}), C$. odorata $(142.80 \pm 1.76 \mu \mathrm{g} / \mathrm{mL})$, C. verbenaceae $(130.00 \pm 1.081 .77 \mu \mathrm{g} / \mathrm{mL}), C$. dinisii $(106.31 \pm$ $2.23 \mu \mathrm{g} / \mathrm{mL}$ ) and the most cytotoxic EO was of the one from S. guianensis $(78.02 \pm 1.19 \mu \mathrm{g} / \mathrm{mL})$ (Table 1).

EOs with higher selectivity indexes were those from $F$. galbaniflua (3.94), M. chamomilla (2.87) and M. officinalis 
Table 1 EOs biological potential and selectivity indexes (SI) for L. amazonensis ( $\left(\mathrm{C}_{50} / 24 \mathrm{~h}\right.$ ) promastigotes and $\mathrm{L}_{6}$ cells $\left(\mathrm{CC}_{50} / 24 \mathrm{~h}\right.$ )

\begin{tabular}{|c|c|c|c|}
\hline \multirow[t]{2}{*}{ Essential oils } & L. amazonensis & L6 cells & \multirow[t]{2}{*}{$\mathrm{SI} \mathrm{I}^{9}$} \\
\hline & $\mathrm{IC}_{50}^{\mathrm{a}} \pm \mathrm{DP}(\mu \mathrm{g} / \mathrm{mL})$ & $C C_{50}{ }^{f} \pm D P(\mu \mathrm{g} / \mathrm{mL})$ & \\
\hline Litsea cubeba & $\mathrm{Nl}^{\mathrm{e}}$ & $180.72 \pm 1.37$ & - \\
\hline Matricaria chamomilla & $60.16 \pm 4.24$ & $173.04 \pm 1.24$ & 2.87 \\
\hline Elettaria cardamomum & $>500.00^{b}$ & $439.57 \pm 2.27$ & - \\
\hline Lavandula officinalis & $>500.00$ & $377.56 \pm 8.91$ & - \\
\hline Cinnamomum camphora & $>500.00$ & $>500.00$ & - \\
\hline Myroxylon peruiferum & $162.25 \pm 1.57$ & $160.80 \pm 1.62$ & 0.99 \\
\hline Salvia sclarea & $325.92 \pm 8.58$ & $375.37 \pm 3.62$ & 1.15 \\
\hline Bulnesia sarmientoi & $85.56 \pm 3.38$ & $163.46 \pm 1.77$ & 1.91 \\
\hline Ferula galbaniflua & $95.70 \pm 1.82$ & $377.26 \pm 2.71$ & 3.94 \\
\hline Pelargonium graveolens & $363.71 \pm 6.77$ & $368.39 \pm 3.90$ & 1.01 \\
\hline Cananga odorata & $\mathrm{NI}$ & $142.80 \pm 1.76$ & - \\
\hline Foeniculum officinalis & $328.28 \pm 6.80$ & $368.27 \pm 3.81$ & 1.12 \\
\hline Cordia verbenaceae & $64.75 \pm 2.04$ & $130.00 \pm 1.08$ & 2.01 \\
\hline Melissa officinalis & $132.02 \pm 3.14$ & $297.45 \pm 1.32$ & 2.25 \\
\hline Siparuna guianensis & $48.55 \pm 3.64$ & $78.02 \pm 1.19$ & 1.60 \\
\hline Cinnamodendron dinisii & $54.05 \pm 4.88$ & $106.31 \pm 2.23$ & 1.97 \\
\hline Anfotericina $B^{C}$ & $(0.083 \pm 0.003 \mu \mathrm{g} / \mathrm{mL})$ & $\mathrm{NI}$ & - \\
\hline $\mathrm{DMSO}^{\mathrm{d}}$ & $\mathrm{Nl}$ & $\mathrm{Nl}$ & - \\
\hline
\end{tabular}

a) $\mathrm{IC}_{50} \pm \mathrm{DP}$ : the concentration able to cripple $50 \%$ of the parasites \pm standard deviation

b) $>500.00: I C_{50}$ greater than the highest concentration tested

c) Amphotericin B - positive control

d) DMSO - negative control

e) NI: no inhibition

f) $\mathrm{CC}_{50}$ : the concentration able to cripple $50 \%$ of cells after $24 \mathrm{~h}$ of treatment \pm standard deviation

g) Selectivity index $-\mathrm{SI}=\mathrm{CC}_{50} \mathrm{~L} 6 / \mathrm{IC}_{50}$ promastigotes

(2.25), but all were more cytotoxic and less selective than Amphotericin B, because the reference drug did not show $\mathrm{CC}_{50} / 24 \mathrm{~h}$ value.

\section{Chemical composition}

The GC-MS analyses were performed for EOs that showed the lower values of $\mathrm{IC}_{50}$ and/or the higher SI values (Table 2). The analysis identified the main constituents as $\beta$-farnesene (52.73\%), bisabolol oxide (12.09\%), $\alpha$-farnesene (10.34 \%) for M. chamomilla; $\alpha$-copaene (13.41 \%), guaiol (9.35\%), safrole (8.35\%) and $\delta$-cadinene $(7.08 \%)$ for $M$. peruiferum; linalool (28.80\%) and linalyl acetate $(60.08 \%)$ for S. sclarea; guaiol (48.29\%) and 2-undecanone (19.49\%) for B. sarmientoi; ethyl phthalate (13.09 \%) and methyl-8-pimaren-18-oate (41.82 \%) for F. galbaniflua; and neral (37.18\%) and geranial $(5.02 \%)$ for $M$. officinalis. According to Andrade et al. [20], EO from $C$. dinisii fresh leaves is composed mainly by $\alpha$-pinene (35.41 \%), $\beta$-pinene (17.81\%), sabinene (12.01\%) and bicyclogermacrene (7.59\%). EO from S. guianensis fresh leaves contains $\beta$-myrcene (13.14 \%), germacrene-D (8.68 \%) and bicyclogermacrene (16.71\%).

\section{Discussion}

According to the classification of cytotoxicity and antileishmanial activity for extracts and fractions derived from plants and natural products defined by Study Program and Disease Control [27], the evaluated EOs are classified as moderately toxic $\left(100<\mathrm{CC}_{50} \leq\right.$ $1000 \mu \mathrm{g} / \mathrm{mL}$ ), except the EO from S. guainensis, which was classified as toxic $\left(10<\mathrm{CC}_{50} \leq 100 \mu \mathrm{g} / \mathrm{mL}\right)$. Regarding the antileishmanial activity only EOs from $S$. guianensis, $C$. dinisii, $M$. chamomilla, $C$. verbenaceae, $B$. sarmientoi, F. galbaniflua and M. officinalis are considered moderately active $\left(50<\mathrm{IC}_{50} \leq 150 \mu \mathrm{g} / \mathrm{mL}\right)$. The others are considered not active.

Considering the chemical composition of the EO from M. chamomilla, (E)- $\beta$-farnesene and $(\mathrm{E}, \mathrm{E})-\alpha$-farnesene were found as the major compound group representing $73.07 \%$ of the total composition. These results corroborate with those reported by Machado et al. [28] that found farnesene derivatives as the most representative constituents (22\%) and their bioassays using EO from Lantana camara revealed a significant leishmanicidal activity against $L$. amazonensis $\left(\mathrm{IC}_{50} / 72 \mathrm{~h}=0.25 \mu \mathrm{g} / \mathrm{mL}\right)$, except for the cytotoxic activity, in which the authors 
Table 2 Chemical composition of selected essential oils

\begin{tabular}{|c|c|c|c|c|c|c|c|c|c|c|}
\hline \multicolumn{11}{|c|}{ Content (\%) } \\
\hline$\overline{\mathrm{IRC}}$ & $|\mathrm{R}|$ & Component & $\begin{array}{l}\text { Matricaria } \\
\text { chamomilla }\end{array}$ & $\begin{array}{l}\text { Myroxylon } \\
\text { peruiferum }\end{array}$ & $\begin{array}{l}\text { Salvia } \\
\text { sclarea }\end{array}$ & $\begin{array}{l}\text { Bulnesia } \\
\text { sarmientoi }\end{array}$ & $\begin{array}{l}\text { Ferula } \\
\text { galbaniflua }\end{array}$ & $\begin{array}{l}\text { Melissa } \\
\text { officinalis }\end{array}$ & $\begin{array}{l}\text { Siparuna } \\
\text { guianensis }\end{array}$ & $\begin{array}{l}\text { Cinnamodendron } \\
\text { dinisiia }^{\mathrm{a}}\end{array}$ \\
\hline$\overline{930}$ & 932 & a-pinene & - & - & - & - & - & - & 1.83 & 35.41 \\
\hline 958 & 963 & sabinene & - & - & - & - & - & - & - & 12.01 \\
\hline 961 & 970 & $\beta$-pinene & - & - & - & - & 17.34 & - & - & 17.81 \\
\hline 969 & 971 & 6-metil-5-hepten-2-one & - & - & - & - & - & 3.88 & - & - \\
\hline 975 & 0980 & $\beta$-myrcene & - & - & 1.23 & - & - & - & 13.14 & 1.46 \\
\hline 1018 & 1024 & 1,8-cineole & - & - & - & 8.71 & 3.71 & - & - & 4.37 \\
\hline 1086 & 1092 & linalool & - & - & 28.80 & 2.67 & - & - & - & - \\
\hline 1135 & 1130 & a-terpineol & - & - & 5.14 & - & - & - & - & - \\
\hline 1231 & 1235 & neral & - & - & - & - & - & 37.18 & - & - \\
\hline 1247 & 1252 & linalyl acetate & - & - & 60.08 & 2.64 & - & - & - & - \\
\hline 1263 & 1264 & geranial & - & - & - & - & - & 52.02 & - & - \\
\hline 1282 & 1285 & safrole & - & 8.35 & - & - & - & - & - & - \\
\hline 1287 & 1293 & 2-undecanone & - & - & - & 19.49 & - & - & 1.69 & - \\
\hline 1374 & 1374 & a-copaene & - & 13.41 & - & - & - & - & - & - \\
\hline 1428 & 1432 & trans-a-bergamotene & - & 3.48 & - & - & - & - & - & - \\
\hline 1443 & 1439 & (+)-aromadendrene & - & 2.27 & - & 1.26 & - & - & - & - \\
\hline 1451 & 1455 & (E)- $\beta$-farnesene & 52.73 & - & - & - & - & - & - & - \\
\hline 1455 & 1458 & allo-aromandrendene & - & 5.24 & - & - & - & - & - & - \\
\hline 1470 & 1474 & $y$-gurjunene & - & 5.29 & - & - & - & - & - & - \\
\hline 1476 & 1482 & germancrene-D & 3.42 & - & - & - & - & - & 8.68 & - \\
\hline 1478 & 1479 & ar-curcumene & - & 5.05 & - & - & - & - & - & - \\
\hline 1481 & 1487 & $\beta$-selinene & - & 3.27 & - & - & - & - & - & - \\
\hline 1488 & 1497 & bicyclogermancrene & - & - & - & - & - & - & 16.71 & 7.59 \\
\hline 1504 & 1505 & $(\mathrm{E}, \mathrm{E})$-a-farnesene & 10.34 & - & - & - & - & - & - & - \\
\hline 1504 & 1507 & $\beta$-bisabolene & - & 2.09 & - & - & - & - & - & - \\
\hline 1510 & 1511 & $\delta$-amorfene & - & 6.59 & - & - & - & - & - & - \\
\hline 1520 & 1522 & $\delta$-cadinene & - & 7.08 & - & - & - & - & 1.04 & 0.14 \\
\hline 1576 & 1577 & (-)-spathulenol & - & - & - & 5.79 & - & - & 4.16 & 1.88 \\
\hline 1594 & - & diethyl phthalate & - & - & - & - & 13.09 & - & - & - \\
\hline 1601 & 1600 & Guaiol & - & 9.35 & - & 48.29 & - & - & - & - \\
\hline 1630 & - & $(-)$-sinularene & - & 5.81 & - & - & - & - & - & - \\
\hline 1652 & 1649 & $\beta$-eudesmol & - & 2.10 & - & - & - & - & - & - \\
\hline 1656 & 1656 & bisabolol oxide B & 12.09 & - & - & - & - & - & - & - \\
\hline 1657 & 1658 & t-cadinol & - & - & - & 1,35 & - & - & 4.14 & - \\
\hline 1685 & 1685 & a-bisabolol & 9.83 & - & - & - & - & - & 3.35 & - \\
\hline 1732 & - & camazulene & 2.30 & - & - & - & - & - & - & - \\
\hline- & - & elixene & - & - & - & - & 5.87 & - & - & - \\
\hline- & - & methyl 8 (14)-pimaren-18- oate & - & - & - & - & 41.82 & - & - & - \\
\hline- & - & $\mathrm{NI}$ & - & - & - & - & 9.39 & - & - & - \\
\hline & & Total identified (\%) & 90.72 & 79.38 & 94.05 & 88.85 & 81.83 & 93.08 & 55.25 & 80.67 \\
\hline
\end{tabular}

IRI literature retention rate [22], IRc retention ratio calculated by Kovats' equation. a) Described by Andrade et al. [20] 
obtained high values on Brine shrimp $\left(\mathrm{CC}_{50} 10 \mu \mathrm{g} / \mathrm{mL}\right)$. Subsequently, Gawde et al. [29] observed that the chemical composition of $M$. chamomilla was similar to the one found in our study ( $\beta$-farnesene, $\alpha$-bisabolol oxide B, chamazulene) but no leishmanicidal activity on $L$. donavani was observed.

Studies on the chemical composition and biological activity of $M$. peruiferum EO are scarce. The literature reports (E) and (Z)-nerolidol, $\alpha$-bisabolol and (E, E)-farnesol as its major components [30] but those compounds were not identified in the present study. Santos et al. [18] reported high levels of $\alpha$-copaene in EO from Copaifera reticulata as well as for EO from $M$. peruiferum. The last one showed growth inhibitory activity for L. amazonensis with $\mathrm{IC}_{50} / 72 \mathrm{~h}$ values of $5 \mu \mathrm{g} / \mathrm{mL}$ for promastigotes and low cytotoxicity on J774G8 macrophages.

Ghannadi and Amree [31] have already described the EO composition obtained from the fresh oleogum resin and latex of Iranian F. galbaniflua (synonym F. gummosa) and the main constituents of this monoterpene rich oil were $\beta$-pinene (58.8\%). Other studies also indicate $\beta$-pinene as the major compound from the fresh oleogum resin and latex of this same specie [32, 33], which corroborates our results. The presence of methyl 8-(14)-pimaren-18-ate, a diterpene esters hydrocarbons, has been reported on rosin, a solid form of resin obtained from pines and some other plants; and also in the Cretaceous resins from India and Myanmar [34, 35]. To our knowledge, there is no antileishmanial activity reports related to this EO to date.

Rodilla et al. [36] determined the chemical composition of EO from B. sarmientoi. In accordance with our work, they identified guaiol as its major component. Studies with EO from Endlicheria bracteolata, which has $72.12 \%$ of guaiol in its composition, showed $\mathrm{IC}_{50}$ of $7.93 \mu \mathrm{g} / \mathrm{mL}$ for L. amazonensis and presented a $\mathrm{CC}_{50}$ of $15.14 \mu \mathrm{g} / \mathrm{mL}$ for J774.G8 macrophages [37]. The antileishmanial activity may be attributed to the presence of a hydroxyl group of alcohol characteristics in the guaiol, especially in the exocyclic portion of the molecule [36].

The presence of linalyl acetate and linalool as the major compounds in S. sclarea EO (total of $88.88 \%$ ) corroborate to the results presented by Pitarokili et al. [38] that evaluated the EO composition of S. sclarea originated from two localities in Greece, and by Kuźma et al. [39] that evaluated the EO composition from $S$. sclarea plants generated in vitro. On the other hand, antileishmanial activity of linalool-rich EO from leaves of Croton cajucara against L. amazonensis was previously evaluated by Rosa et al. [40], they were able to demonstrate morphological changes in L. amazonensis promastigotes when treated with $15 \mathrm{ng} / \mathrm{mL}$ of that EO. In this study the cell lysis was observed within $1 \mathrm{~h}$, indicating that the antileishmanial activity observed is directly related to the presence of linalool, due to the existence of a hydroxyl group in the organic alcohol function.

As in our study, the presence of the isomers of citral, neral and geranial are constantly reported in the chemical composition of the EO from M. officinalis [41-43]. Regarding the antileishmanial activity, Mikus et al. [44] reported an $\mathrm{IC}_{50} / 72 \mathrm{~h}$ of $7 \mu \mathrm{g} / \mathrm{mL}$ for $L$. major, a $\mathrm{CC}_{50} /$ $72 \mathrm{~h}$ of $25.5 \mu \mathrm{g} / \mathrm{mL}$ in HL-60 cells and SI of 3.6, higher than those observed in our study. Another study has already showed that citral presents activity against $T$. cruzi, possibly by inducing cell membrane lysis with leakage of cytoplasm [45].

The EO from C. dinisii and S. guianensis showed weak inhibitory effect on the protozoan $T$. cruzi with values of $\mathrm{IC}_{50} / 24 \mathrm{~h}=209.30 \mu \mathrm{g} / \mathrm{mL}$ and $282.93 \mathrm{mg} / \mathrm{mL}$, respectively. These values are higher when compared to those obtained in the study for $L$. amazonensis, 54.05 and $48.55 \mu \mathrm{g} / \mathrm{mL}$, respectively [25].

The mechanism of action by which EOs inhibits parasite growth is still not well known, but previous studies have suggested that structural and morphological changes are caused by drugs that inhibit ergosterol synthesis, or interact with the membrane ergosterol $[19,46]$. Other studies indicated that the activity of essential oils on parasites is mainly due to terpene composition. Terpenes are responsible for the hydrophobic characteristic of EOs, thus allowing their diffusion through the parasite cell membrane, affecting intracellular metabolic pathways and organelles [47].

\section{Conclusion}

F. galbaniflua EO is effective against L. amazonensis promastigotes forms and has low cytotoxic activity. Thus, it represents a strong candidate for future studies in order to comprehend its biological activity agaisnt $L$. amazonensis.

The promising results of this study offer prospects for further research, as the evaluation of the antileishmanial potential of the major compounds and the elucidation of their molecules may, in the future, contribute to the discovery of effective drugs derived from plants for the treatment of parasitic diseases.

\footnotetext{
Acknowledgements

The autors are indebted with Central Analítica do Instituto de Química da Universidade de Brasília (CAIQ/UnB) for GC-MS analysis.

Funding

This work was supported by Coordenação de Aperfeiçoamento de Pessoal de Nível Superior (CAPES): Programa Nacional de Incentivo a Pesquisa em Parasitologia Básica (CAPES grant no: 23038.005298/2011-83); Conselho Nacional de Desenvolvimento Científico e Tecnológico (CNPq Chamada 79/2013-MCTI/CNPq/FNDCT); Fundação de Amparo à Pesquisa do Distrito Federal (FAP-DF- 193.001.076/2015); PGCTS-FCE/UNB; Financiadora de Estudos e Projetos (FINEP); Decanato de Pesquisa e Pós-graduação/UnB (DPP/UnB).
} 


\section{Availability of data and materials}

The datasets supporting the conclusions of this article are included within the article.

\section{Authors' contributions}

IMDB and JMS conceived the research idea. MAA, CSA and CLS conducted the experiment, analyzed and interpreted the data as well as prepared the first draft. MLS supported the conduct of the analysis and interpreted the data of CG-MS. IMDB, JMS, FNM, and CSA critically read and revised the paper. All authors have read and approved the paper before its final submission.

\section{Competing interests}

The authors declare that they have no competing interests.

\section{Consent for publication}

Not applicable.

\section{Ethics approval and consent to participate}

Not applicable.

\section{Author details}

'Pathogen-Host Interface Laboratory, Department of Cell Biology, The University of Brasília, Campus Darcy Ribeiro, Bloco I, Brasília, DF CEP 70910-900, Brazil. ${ }^{2}$ Faculty of Ceilândia, The University of Brasília, Brasília, Brazil. ${ }^{3}$ Institute of Chemistry, The University of Brasilia, Brasilia, Brazil.

Received: 20 April 2016 Accepted: 13 October 2016

Published online: 08 November 2016

\section{References}

1. Homsi Y, Makdisi G. Leishmaniasis: a forgotten disease among neglected people. Internet J Health. 2009;11:1-5. http://ispub.com/JH/11/2/9151. Accessed 04 Apr 2016

2. de Vries HJ, Reedijk SH, Schallig HD. Cutaneous leishmaniasis: recente developments in diagnosis and management. Am J Clin Dermatol. 2015;16:99-109.

3. WHO. World Health Organization. Investing to overcome the global impact of neglected tropical diseases: 3rd WHO report on neglected diseases. 2015. http://apps.who.int/iris/bitstream/10665/152781/1/9789241564861_eng.pdf. Accessed 04 Apr 2016

4. Alvar J, Vélez ID, Bern C, Herrero M, Desjeux P, Cano J, et al. Leishmaniasis worldwide and global estimates of its incidence. PloS One. 2012;7:e35671.

5. Ejaz A, Raza N, Iftikhar N. Recurrent cutaneous leishmaniasis presenting as sporotrichoid abscesses: a rare presentation near Afghanistan border. Dermatol Online J. 2007; 13:15. http://www.ncbi.nlm.nih.gov/pubmed/ 17498434. Accessed 04 Apr 2016.

6. WHO. World Health Organization. Technical Report Series 949-control of leishmaniases. Report of a meeting of the WHO Expert Committee on the Control of Leishmaniases, Geneva, 22-26 March 2010. http://whqlibdoc. who.int/trs/WHO_TRS 949 eng.pdf. Accessed 04 Apr 2016.

7. Name RQ, Borges KT, Nogueira LSC, Sampaio JHD, Tauil PL, Sampaio RNR. Clinical, epidemiological and therapeuthic study of 402 patients with american cutaneous leishmaniasis attended at University Hospital of Brasilia, DF, Brazil. Ann Bras Dermatol. 2005:80:249-54.

8. González U, Pinart M, Rengifo-Pardo M, Macaya A, Alvar J, Tweed JA. Interventions for American cutaneous and mucocutaneous leishmaniasis. Cochrane Database Syst Rev. 2009;2:1-175. http://www.ncbi.nlm.nih.gov/ pubmed/19370612. Accessed 04 Apr 2016.

9. Minodier P. Parola P. Cutaneous leishmaniasis treatment. Travel Med Infect Dis. 2007;5:150-8.

10. Reithinger R, Dujardin JC, Louzir H, Pirmez C, Alexander B, Brooker S. Cutaneous leishmaniasis. Lancet Infect Dis. 2007;7:581-96.

11. Ben Salah A, Ben Messaoud N, Guedri E, Zaatour A, Ben Alaya N, Bettaieb J. Topical paromomycin with or without gentamicin for cutaneous leishmaniasis. N Engl J Med. 2013;368:524-32.

12. Utaile M, Kassahun A, Abebe T, Hailu A. Susceptibility of clinical isolates of Leishmania aethiopica to miltefosine, paromomycin, amphotericin B and sodium stibogluconate using amastigote-macrophage in vitro model. Exp Parasitol. 2013;134:68-75.

13. Azeredo CMO, Santos TG, Maia BHLNS, Soares MJ. In vitro biological evaluation of eight different essential oils against Trypanosoma cruzi, with emphasis on Cinnamomum verum essential oil. BMC Complementary Altern Med. 2014;14:309-15.

14. Bakkali F, Averbeck S, Averbeck D, Idaomar M. Biological effects of essential oils - A review. Food Chem Toxicol. 2008;46:446-75.

15. Singh G, Maurya S, Lampasona MP, Catalan CAN. A comparison of chemical, antioxidant and antimicrobial studies of cinnamon leaf and bark volatile oils, oleoresins and their constituents. Food Chem Toxicol. 2007;45:1650-61.

16. Victoria FN, Lenardão EJ, Savegnago L, Perin G, Jacob RG, Alves D, Da Silva WP, Motta AS, Nascente OS. Essential oil of the leaves of Eugenia uniflora L: antioxidant and antimicrobial properties. Food Chem Toxicol. 2012;50:2668-74.

17. Ueda-Nakamura T, Mendonça-Filho RR, Morgado-Díaz JA, Maza PK, Prado Dias Filho B, Cortez DAD, Alviano DS, Rosa MS, Lopes AH, Alviano CS, Nakamura CV. Antileishmanial activity of eugenol-rich essential oil from Ocimum gratissimum. Parasitol Int. 2006;55:99-105.

18. Santos AO, Ueda-Nakamura T, Dias Filho BP, Veiga Junior VF, Pinto AC Nakamura CV. Effect of Brazilian copaiba oils on Leishmania amazonensis. J Ethnopharmacol. 2008;120:204-8.

19. Medeiros MGF, Silva AC, Citó AMGL, Borges AR, Lima SG, Lopes JAD, Figueiredo RCBQ. In vitro antileishmanial activity and cytotoxicity of essential oil from Lippia sidoides Cham. Parasitol Int. 2011;60:237-41.

20. Andrade MA, Cardoso MG, Andrade J, Silva LF, Teixeira ML, Resende JV, Figueiredo ACS, Barroso J. Chemical Composition and Antioxidant Activity of Essential Oils from Cinnamodendron dinisii Schwacke and Siparuna guianensis Aublet. Antioxidants. 2013;2:384-97.

21. Guimarães LGL, Cardoso MG, Zacaroni LM, Lima RK, Pimentel F, Morais AR. Influência da luz e da temperatura sobre a oxidação do óleo essencial de capim-limão (Cymbopogon citratus (D.C.) STAPF). Quim Nova. 2008:31:1476-80,

22. Adams RP. Identification of Essential oil Components by Gas Chromatography/ Mass Spectroscopy. 4th ed. IL: Allured Publishing Corporation; 2007.

23. O'Brien J, Wilson I, Orton T, Pognan F. Investigation of the Alamar Blue (resazurin) fluorescent dye for the assessment of mammalian cell cytotoxicity. Eur J Biochem. 2000;267:5421-6.

24. Raz B, Iten M, Grether-Buhler Y, Kaminsky R, Brun R. The Alamar Blue assay to determine drug sensitivity of African trypanosomes ( $T$. b. rhodesiense and T. b. gambiense) in vitro. Acta Trop. 1997;68:139-47.

25. Andrade MA, Cardoso MG, Gomes MS, Azeredo CMO, Batista LR, Soares MJ, Rodrigues LMA, Figueiredo ACS. Biological Activity of the Essential Oils from Cinnamodendron dinisii and Siparuna guianensis. Braz J Microbiol. 2015;46:189-94.

26. Ferreira DF. SISVAR: A computer statistical analysis system. Cienc Agrotec. 2008:6:36-41. doi:10.1590/S1413-7054201 1000600001. Accessed 04 Apr 2016.

27. Rios YK, Otero AC, Muñoz DL, Echeverry M, Robledo SM, Yepes MA. Actividad citotóxica y leishmanicida in vitro del aceite de manzanilla (Matricaria chamomilla). Rev Colomb Cienc Quím Farm. 2008;37:200-11. http://www.revistas. unal.edu.co/index.php/rccquifa/article/view/15254/16051. Accessed 04 Apr 2016.

28. Machado RRP, Valente Júnior W, Lesche B, Coimbra ES, Souza NB, Abramo C, et al. Essential oil from leaves of Lantana camara: a potential source of medicine against leishmaniasis. Rev Bras Farmacogn. 2012;22:1011-7.

29. Gawde A, Cantrell CL, Zheljazkov VD, Astatkie T, Schlegel V. Steam distillation extraction kinetics regression models to predict essential oil yield, composition, and bioactivity of chamomile oil. Ind Crops Prod. 2014;58:61-7.

30. Wanner J, Schmidt E, Bail S, Jirovetz L, Buchbauer G, Gochev V, et al. Chemical composition and antibacterial activity of selected essential oils and some of their main compounds. Nat Prod Commun. 2010;5:1359-64. http://www.ncbi.nlm.nih.gov/pubmed/20922991. Accessed 04 Apr 2016.

31. Ghannadi A, Amree S. Volatile oil constituents of Ferula gummosa Boiss. from Kashan, Iran. J Essent Oil Res. 2002;14:420-42.

32. Kouyakhi ET, Naghavi MR, Alayhs M. Study of the essential oil variation of Ferula gummosa samples from Iran. Chem Nat Compounds. 2008:44:124-6.

33. Sahebkar A, Iranshahi M. Volatile Constituents of the Genus Ferula (Apiaceae): A Review. J Essent Oil-Bear Plants. 2011;14:504-31.

34. Chang T, Mead TE, Zlnkel DF. Mass Spectra of Diterpene Resin Acid Methyl. J Am Oil Chem Soc.1 presented in part at the Meeting of the American Chemical Society, Chicago. 1970. http://link.springer.com/article/10.1007/ BF02544660. Accessed 05 Apr 2016.

35. Dutta S, Mallick M, Kumar K, Mann U, Greenwood PF. Terpenoid composition and botanical affinity of Cretaceous resins from India and Myanmar. Int J Coal Geol. 2011;85:49-55.

36. Rodilla JM, Silva LA, Martinez N, Lorenzo D, Davyt D, Castillo L, Giménez C, Cabrera R, González-Coloma A, Zrostlíkováf J, Dellacassa E. Advances in the identification and agrochemical importance of sesquiterpenoids from Bulnesia sarmientoi essential oil. Ind Crops Prod. 2011;33:497-503. 
37. Rottini MM, Amaral ACF, Ferreira JLP, Silva JRA, Taniwaki, Souza CSF, d'Escoffier LN, Almeida-Souza F, Hardoim DJ, Costa SCG, Calabrese KS. In vitro evaluation of (-) a-bisabolol as a promising agent against Leishmania amazonensis. Exp Parasitol. 2015;148:66-72.

38. Pitarokili D, Couladis M, Petsikos-Panayotarou N, Tzakou O. Composition and antifungal activity on soil-borne pathogens of the essential oil of Salvia sclarea from Greece. J Agric Food Chem. 2002;50:6688-91.

39. Kuźma L, Kalemba D, Różalski M, Różalska B, Więckowska-Szakiel M, Krajewska U, Wysokińska H. Chemical composition and biological activities of essential oil from Salvia sclarea plants regenerated in vitro. Molecules. 2009;14:1438-47.

40. Rosa MSS, Mendonça-Filho RR, Bizzo HR, Rodrigues IA, Soares RMA, Souto-Padrón T, Alviano CS, Lopes AHCS. Antileishmanial activity of a linalool-rich essential oil from Croton cajucara. Antimicrob Agents Chemother. 2003:47:1895-901.

41. Sadraei H, Ghannadib A, Malekshahia K. Relaxant effect of essential oil of Melissa officinalis and citral on rat ileum contractions. Fitoterapia. 2003;74:445-52

42. Mimica-Dukic N, Bozin B, Sokovic M, Simin N. Antimicrobial and Antioxidant activities of Melissa officinalis L. (Lamiaceae) essential oil. J Agric Food Chem. 2004;52:2485-9.

43. Silva S, Sato A, Lage CLS, Gil S, Silva RA, Azevedo, Almeida D, Esquibel MA. Essential oil composition of Melissa officinalis L. in vitro produced under the influence of growth regulators. J Braz Chem Soc. 2005;16:1387-90.

44. Mikus J, Harkenthal M, Steverding D, Reichling J. In vitro effect of essential oils and isolated mono- and sesquiterpenes on Leishmania major and Trypanosoma brucei. Planta Med. 2000;66:366-8.

45. Santoro GF, Cardoso MG, Guimarães LGL, Freire JM, Soares MJ. Antiproliferative effect of the essential oil of Cymbopogon citratus (DC) Stapf (lemongrass) on intracelular amastigotes, bloodstream trypomastigotes and culture epimastigotes of Trypanosoma cruzi (Protozoa: Kinetoplastida). Parasitology. 2007;13:1649-56. http://www.ncbi.nlm.nih.gov/pubmed/ 17686189. Accessed 05 Apr 2015.

46. Brenzan MA, Nakamura CV, Filho BPD, Ueda-Nakamura T, Young MCM Cortez DAG. Antileishmanial activity of crude extract and coumarin from Calophyllum brasiliense leaves against Leishmania amazonensis. Parasitol Res. 2007;101:715-22.

47. Borges AR, Aires JR, Higino TM. Trypanocidal and cytotoxic activities of essential oils from medicinal plants of Northeast of Brazil. Exp Parasitol. 2012;132:123-8

\section{Submit your next manuscript to BioMed Central and we will help you at every step:}

- We accept pre-submission inquiries

- Our selector tool helps you to find the most relevant journal

- We provide round the clock customer support

- Convenient online submission

- Thorough peer review

- Inclusion in PubMed and all major indexing services

- Maximum visibility for your research

Submit your manuscript at www.biomedcentral.com/submit 